\title{
Considering Football Teams from a Resource Dependency Theory Perspective
}

\author{
Samba Sowe \\ School of Business, Ibn Haldun University. \\ No:2 34494 Basaksehir/ISTANBUL/TURKEY
}

\begin{abstract}
Football is known to be one of the most popular and widely viewed sports around the world. This sport is a wellfollowed source of entertainment by people from all four corners of the world and its recognition is tremendously increasing. The aim of this study is to examine the actions and strategies football teams use/implement in other to reduce their resource dependency on other teams. The findings of our literature review indicate that football teams use mergers, hiring, executive succession and training as strategies in reducing their resource dependency on other teams. Despite few studies or non-looking at resource dependency theory in a football team perspective this research tried to look at the strategic decisions they can take (football teams) in a highly competitive environment to reduce their resource dependency on other teams. The limitations of our paper includes the lack of enough reference materials when it comes to football most specifically the strategies that football teams use in reducing their resource dependency on other teams as well as our examples being limited to only England and Spain which is not a total representation of all football teams.
\end{abstract}

Keywords Football, Football Teams, Resource Dependency Theory, Strategies

DOI: $10.7176 / \mathrm{JTHS} / 43-01$

Publication date:September $30^{\text {th }} 2019$

\section{Introduction}

Being one of, if not the most popular and followed sport in the world has made it one of the most lucrative business ventures for many. Football or soccer as named in America and Canada can be argued as the most popular ball game around the world. The game requires a lot of energy and hard work to play and hence the need for getting skills and speed as a footballer in a competitive team. Many believe that the sport started in England in 1863 due to the split of rugby football and association football (name of football at the time). This split gave birth to the Football Association in England in the same year, which shows it becoming the first council responsible for the day to day running of the game in the country (FIFA, 1994). Football I quote "is a game in which two teams of 11 players using any part of their bodies except their hands and arms, try to maneuver the ball into the opposing team's goal. Only the goalkeeper is permitted to handle the ball and may do so only within the penalty area surrounding the goal. The team that scores more goals wins"(Rolling et al., 2019, p. 1).

When it comes to actions and practices that football teams use, none or few papers have addressed them so far. Most of the papers are discussing resource dependence in other perspectives apart from football teams. For instance, Pfeffer and Salancik (1978) concentrated on the issue of resource dependence looking at how organizational environments affect them and how they respond to external constrains. The major issue that is mainly talked about in this piece of work is the relationship of the environment and organizations and how the environment in which they operate influence them (organizations). Malatesta and Smith (2014) in looking at resource dependency concentrated on the strategies (actions and practices) contemporary public and nonprofit management uses in other to cope with the issues of resource problems., Hillman and Dalziel (2003) in their article concentrated of the roles board of directors play in gaining critical resources needed by the organizations they represent. These few examples and many more have discussed resource dependence looking at examples from business organizations or firms but not in football teams and this creates a gap that this study aims to fill.

This article will be concentrating on four major strategies that football teams use to reduce their resources dependence on other teams and these are; Mergers, Hiring, Training and Executive Succession which serves as the scope of our study. These I believe are the major actions and strategies football teams use so as to reduce their dependency ratio on other teams for resources. They could also be seen to encompass most of the major strategies, actions and practices organizations use in reducing resource dependency. It is important for any team that wants to be part of the best in a particular league they play in to be able to hire one of the best footballers, train them well, appoint qualified, influential and experienced managers and also make mergers when it is necessary. These strategies when implemented well by a particular team it goes a long way in reducing their dependency on resources from other teams. The good thing about not being dependent on someone for resources is that you are able to do what ever you want without waiting for anyone or needing something from someone.

On the other hand, when someone is giving you a particular resource for the running of your football club or organization there is a high possibility that they will have an influence over the decisions you make and sometimes what you want to do and what they want you to do may differ and this may create problems. A 
famous Jamaican musician Sizzla Kalonji in his song said and I quote "don't bite the hands that feed you". This is the same as don't go against the person that gives you resources. For that being the case, it has been a very important issue for organizations and football teams included to work very hard towards reducing their dependence on other teams for their critical resources. As the saying goes " no man is an Island" teams are also aware that they may need some resources from other teams but are trying to reduce this dependency especially on critical resources by using some of the above-mentioned actions and practices. Football as alluded to before is among the most popular sports and so it is prudent to know the strategies they used for their high productivity levels. Before getting into the strategies football teams use in reducing their resource dependency it is of paramount importance to give a comprehensive review of the Resource Dependency Theory, which is used as the theoretical framework of our paper.

Study Aim: The aim of this study is to examine the actions and strategies football teams use/implement in other to reduce their resource dependency on other teams.

Study Question: What kinds of actions and strategies do football teams use/implement to reduce their resource dependency on other teams?

\section{Literature Review}

Resource dependency theory since its inception has become one of the most influential theories in organizational theory and strategic management. Resources are an integral part of an organizations survival. Most organizations have a life cycle and in the process of surviving through this cycle they need some resources to survive and without which they probably will die as in will not exist anymore. It is the role of managers of companies or firms to reduce environmental uncertainty and dependence on critical and scares resources so as to increase the chances of their organizations living a long and productive life. If an organization doesn't have any control over their environment and always depend on the help of other organizations for their own resources their survival rate will be very low compared to the organizations that have the resources they need. If firms or organizations are largely dependent on the resources of other firms they are vulnerable to exploitation and low productivity and this also reduces their influence and bargaining power in that business environment. This is the more reason why it is important for a firm to be able to get its own resources that it needs for its survival.

Resource dependence theory propagates for the importance of the environment in understanding the organization. In their book, Pfeffer and Salancik (1978) concentrated on how organizational environments affect and constrain the organizations themselves and how they respond to external constrains. The major issue that is mainly talked about in this piece of work is the relationship of the environment and organizations and how the environment in which they operate influence them (organizations). For organizations that have cooping mechanism and strategies survival becomes easier compared to the ones that do not have strategies to cope with changing environments. To them, organizations are constrained and affected by their environments and that they act to attempt to manage resource dependencies. They also postulated that there is a huge connection between environmental constraint and internal organizational dynamics. They additionally argued that companies seek to build alliances to manage dependence but usually with companies that are in social position to be trusted. Some of these alliances maybe in the form of mergers, cooptation, cooperation's, joint ventures etc. for the purpose of surviving in the environment they are in (Pfeffer \& Salancik, 1978).

Hillman et al (2009) like Pfeffer and Salancik (1978) also dealt with the importance of the environment in the resource dependency theory concept. They were mostly concentrated on the five actions that firms can take to minimize environmental dependences so as to help them survive longer. These five actions were; "(a) mergers/vertical integration, (b) Joint Ventures and other interorganizational relationships, (c) boards of directors, (d) political action, and (e) executive succession" (Hillman et al. 2009, p.1405). Firstly, Mergers and vertical integration to them are strategies organizations use to reduce their competition in the market as well as their resource dependence on other firms. Organizations reduce these competition by merging with a firm with grate potentials in other to gain a better bargaining power, high productivity and if possible a source of competitive advantage. These mergers help them in gaining more resources at their disposal leading to a reduction in their dependency on recourses from other firms. Second, are joint ventures which are done via strategic alliances, R\&D agreements, research consortia, joint-marketing agreements, buyer-supplier relationships etc. Joint ventures involve the collaboration of more than one organization to work on a particular project or product. In joint ventures, all the organizations involved are expected to contribute their quota in making the project a success and these includes their resource contribution. Organizations in this process come together in order to produce a particular product while mutually benefiting the parties involved. Firm in this system instead of dependent on other firms for help they work with them together to make things happen. Third, Boards of directors who are seen as positive contributors to firms by enabling their firms minimize dependence and also helping them gain resources through their influence. When the people of a board are powerful members of the community in which the firm operates this gives them a bigger influence in lobbying resources and power for the firm. Forth, political action, which firms, tries to influence for the interest of their development and survival. 
This involves a firm board trying to influence political decisions that are geared towards helping their organizations.

Salancik (1978) as cited by Hillman et al (2009) noted that, "the organization, through political mechanisms, attempts to create for itself an environment that is better for its interest and that organizations may use political means to alter the condition of the external economic environment. In doing so, firms actively seek to create their environment by trying to shape government regulations that produce a more favorable environment" (p. 1411). The fifth strategy is Executive succession, which is done within an organization in response to external threats created by an unpredictable environment in the struggle to reduce resource dependency. It could be seen as a strategic response to environmental contingencies. Executive succession can go a long way in reducing environmental dependencies especially if the appointed CEO is well suited for the existing environmental realities at the time of his tenure. Hillman et al. (2009) postulated that, all the five mentioned strategies are being used by organizations mostly as coping mechanisms for environmental uncertainties.

On their part, Malatesta and Smith (2014) in looking at resource dependency concentrated on the strategies (actions and practices) contemporary public and nonprofit management uses in other to cope with the issues of resource problems. They postulated that in order to solve the problems of limited resources faced by their institutions managers come up with strategies and approaches and among these are; joining an association, creating alliances, making contracts, cooptation and mergers. To them when an organization is dependent of resources from another organization it makes their situation uncertain and vulnerable and so it is the job of the manager to decide what level of dependency is okay for his/her company. These decisions the manager takes may either help the organization be more autonomous or more dependent on others for their survival, which is a risk of failure (Malatesta \& Smith, 2014).

Furthermore, Hillman and Dalziel (2003) in their article concentrated of the roles board of directors play in gaining critical resources needed by the organizations they represent. For them this is the dominant perspective adopted by scholars in the resource dependence and stakeholder traditions. The function a board plays has to do with their ability to bring critical resources that the organization needs for their survival. As a board member of an organization they expect you to help them in getting the resources they need through your influence and also playing an integral part in solving the problems they are faced with. The theoretical underpinning of this function is based on Pfeffer and Salancik's (1978) work on resource dependency as cited in Hillman and Dalziel (2003). Pfeffer and Salancik (1978) as cited in Hillman and Dalziel (2003) assert that boards can provide four primary benefits to an organization and these are I quote: "(1) advice and counsel, (2) legitimacy and good reputation (3) channels for communicating information between external organizations and the firm, and (4) preferential access to commitments or support from important elements outside the firm such as political bodies or other important stakeholder groups" (pp. 387-388). This view is primarily concerned with the board's provision of resources to the organization it represents and how this helps it reducing their dependency on other organization (Hillman $\&$ Dalziel, 2003).

Organizations can be seen as unions, changing their arrangement and designs of behavior to obtain and preserve necessary peripheral resources. Obtaining peripheral resources needed for an organization reduces their dependences on other organizations and also help in creating a situation where other organizations depend on them instead. The resource dependence perspective explains the roles of resources in giving firms power as well as the processes they go through to gain those resources. Organizations in their process of changing their dependency relations they either reduce their dependence on scare resources from other organizations or create a situation or status quo where other organizations will depend on them for resources which increase their power and control level of the market they operate in (Ulrich \& Barney, 1984).

In the spirit of getting a clear and comprehensive understand of our adopted theory for this paper (Resource Dependency Theory) a table summary is provided below comparing it with other popular theories in the study of organizations. 


\begin{tabular}{|c|c|c|c|c|c|c|}
\hline & Basic Premises/Main Tenets & $\begin{array}{l}\text { Role of } \\
\text { Erwironment }\end{array}$ & Role of Manager & $\begin{array}{l}\text { Descriptive and Explanatory } \\
\text { Targets }\end{array}$ & $\begin{array}{l}\text { Main Dependent } \\
\text { Variables }\end{array}$ & $\begin{array}{l}\text { Main Independent } \\
\text { Variables }\end{array}$ \\
\hline $\begin{array}{l}\text { Resource } \\
\text { Depend- } \\
\text { ence }\end{array}$ & $\begin{array}{l}\text { Organizational actors } \\
\text { pursue relationships with } \\
\text { other organizations to } \\
\text { satisfy resource needs; } \\
\text { Resources are the basis } \\
\text { for power and depend- } \\
\text { ence; organizations take } \\
\text { action to manage exter- } \\
\text { nal interdependencies } \\
\text { (either to minimize their } \\
\text { own dependence on oth- } \\
\text { ers or to maximize others' } \\
\text { dependence on them) }\end{array}$ & $\begin{array}{l}\text { Activities and be- } \\
\text { haviors outside } \\
\text { an organization's } \\
\text { control are con- } \\
\text { sidered part of } \\
\text { the erwironment. } \\
\text { The environment } \\
\text { is presumed to } \\
\text { hold valuable } \\
\text { resources that } \\
\text { the organization } \\
\text { needs to survive. }\end{array}$ & $\begin{array}{l}\text { RD presumes some level of } \\
\text { managerial discretion. A } \\
\text { manager who can reduce } \\
\text { uncertainty, help the or- } \\
\text { ganzation obtain critical } \\
\text { resources, and manage } \\
\text { important environmental } \\
\text { dependencies has more } \\
\text { power as a result of } \\
\text { ensuring organizational } \\
\text { survival and success. }\end{array}$ & $\begin{array}{l}\text { RD is applicable to discuss- } \\
\text { ing relationships between } \\
\text { organizations and relation- } \\
\text { ships among units within } \\
\text { organizations. Main tenets } \\
\text { can be used to explain } \\
\text { various organizational strat- } \\
\text { egies including mergers, } \\
\text { leadership choices, affilia- } \\
\text { tions, and alliances. }\end{array}$ & $\begin{array}{l}\text { The power of one } \\
\text { organization or } \\
\text { unit within an } \\
\text { organization } \\
\text { over another; } \\
\text { the depend- } \\
\text { ence of one } \\
\text { organization } \\
\text { or unit over } \\
\text { another; choice } \\
\text { of structure }\end{array}$ & $\begin{array}{l}\text { Criticality of } \\
\text { the resource, } \\
\text { alternatives for } \\
\text { the resource; } \\
\text { discretion }\end{array}$ \\
\hline $\begin{array}{l}\text { Population } \\
\text { Ecology }\end{array}$ & $\begin{array}{l}\text { PE offers an evolutionary } \\
\text { vew of organizations; or- } \\
\text { ganizations descend from } \\
\text { previous forms. The vari- } \\
\text { ations in organizational } \\
\text { structure and the preva- } \\
\text { lence of organizational } \\
\text { forms in the population } \\
\text { arise through selection } \\
\text { rather than adaptation; } \\
\text { organizations incompat- } \\
\text { ible with erwironment are } \\
\text { eventually replaced. }\end{array}$ & $\begin{array}{l}\text { Dynamic changes } \\
\text { in the envi- } \\
\text { ronment can } \\
\text { explain the life } \\
\text { cycle (birth and } \\
\text { mortality) of } \\
\text { organizations; } \\
\text { environmental } \\
\text { determinism. }\end{array}$ & $\begin{array}{l}\text { Adaptation by managers is } \\
\text { deemphasized; manage- } \\
\text { rial strategy can rarely } \\
\text { explain organizational } \\
\text { change; powerful inter- } \\
\text { nal and external forces } \\
\text { inhibit organizational } \\
\text { change and make it dif- } \\
\text { ficult to achieve. }\end{array}$ & $\begin{array}{l}\text { Why are there so many differ- } \\
\text { ent organizational forms? } \\
\text { What are the sources of } \\
\text { changes in the diversity of } \\
\text { organizational forms? PE is } \\
\text { also used to explain vital- } \\
\text { rate interaction between } \\
\text { populations and to examine } \\
\text { "communities of popula- } \\
\text { tions" that share similar } \\
\text { erwironments. }\end{array}$ & $\begin{array}{l}\text { Number of } \\
\text { foundings } \\
\text { or deaths of } \\
\text { organizations; } \\
\text { prevalence of } \\
\text { different types } \\
\text { of organizations } \\
\text { in the popula- } \\
\text { tion }\end{array}$ & $\begin{array}{l}\text { Measures of the } \\
\text { task environ- } \\
\text { ment that } \\
\text { directly affect } \\
\text { the organization } \\
\text { both in time and } \\
\text { proximate loca- } \\
\text { tion; institutional } \\
\text { measures (e.g. } \\
\text { regulatory, politi- } \\
\text { cal pressure) }\end{array}$ \\
\hline $\begin{array}{l}\text { Institutional } \\
\text { Perspec- } \\
\text { tives* }\end{array}$ & $\begin{array}{l}\text { In order to survive organiza- } \\
\text { tions must conform to } \\
\text { rules and norms that } \\
\text { prevail in the environ- } \\
\text { ment. The institutional } \\
\text { environment profoundly } \\
\text { influences the formal } \\
\text { structure of the organiza- } \\
\text { tion; organizations resolve } \\
\text { uncertainty by imitating } \\
\text { what appears to be prev- } \\
\text { alent and appropriate. }\end{array}$ & $\begin{array}{l}\text { The emphasis is } \\
\text { on the social } \\
\text { and cultural en- } \\
\text { vironments and } \\
\text { their effect on } \\
\text { behavioral pre- } \\
\text { dispositions and } \\
\text { organizational } \\
\text { outcomes. }\end{array}$ & $\begin{array}{l}\text { Early versions of the theory } \\
\text { tend to downplay the } \\
\text { role of strategic choice; } \\
\text { rules and norms motivate } \\
\text { decisions. More recent } \\
\text { accounts incorporate the } \\
\text { idea of changing norms } \\
\text { through managerial } \\
\text { strategy interests are } \\
\text { institutionally defined } \\
\text { and shaped. Actions } \\
\text { are chosen by recogniz- } \\
\text { ing a situation as being } \\
\text { familiar and matching to } \\
\text { a set of rules. }\end{array}$ & $\begin{array}{l}\text { How do structure and institur- } \\
\text { tions affect organizational } \\
\text { decisions, inter-organiza- } \\
\text { tional relationships, intra- } \\
\text { organizational relationships, } \\
\text { implementation, and or- } \\
\text { ganizational performance? } \\
\text { What institutions can be } \\
\text { altered to guide organiza- } \\
\text { tional outcomes? }\end{array}$ & $\begin{array}{l}\text { Institutional emer- } \\
\text { gence, con- } \\
\text { formity, conflict, } \\
\text { change, iso- } \\
\text { morphism (early } \\
\text { versions) }\end{array}$ & $\begin{array}{l}\text { Processes which } \\
\text { establish sche- } \\
\text { mas, guidelines } \\
\text { for behavior } \\
\text { (e.g. rules, } \\
\text { norms, and } \\
\text { routines) }\end{array}$ \\
\hline $\begin{array}{c}\text { Transaction } \\
\text { Cost Eco- } \\
\text { nomics }\end{array}$ & $\begin{array}{l}\text { Different governance } \\
\text { mechanisms have differ- } \\
\text { ent attributes. Exchanges } \\
\text { have associated costs. } \\
\text { The choice of governance } \\
\text { mechanism turns on } \\
\text { efficiency-the compara- } \\
\text { tive attributes and trans- } \\
\text { action costs of managing } \\
\text { under one form versus } \\
\text { another. }\end{array}$ & $\begin{array}{l}\text { Uncertainty in the } \\
\text { environment } \\
\text { leads to incom- } \\
\text { plete contract- } \\
\text { ing, which is } \\
\text { to say there } \\
\text { are inevitable } \\
\text { shortcomings in } \\
\text { all governance } \\
\text { forms. }\end{array}$ & $\begin{array}{l}\text { The manager intencs to } \\
\text { choose most efficient } \\
\text { form but the manager is } \\
\text { limited cognitively and } \\
\text { by uncertainty associated } \\
\text { with the dynamics of the } \\
\text { environment. }\end{array}$ & $\begin{array}{l}\text { Why is one organizational } \\
\text { form comparatively better } \\
\text { than others? What are the } \\
\text { transaction costs associated } \\
\text { with each form? Should } \\
\text { organizations produce } \\
\text { internally or rely on external } \\
\text { organizations (make vs. } \\
\text { buy)? How should exchange } \\
\text { relationships be structured? }\end{array}$ & $\begin{array}{l}\text { Governance } \\
\text { structure- } \\
\text { organizational } \\
\text { form; contract } \\
\text { design }\end{array}$ & $\begin{array}{l}\text { Asset specificity, } \\
\text { cost associated } \\
\text { with exchange } \\
\text { (e.g. contract } \\
\text { specification, } \\
\text { monitoring, } \\
\text { enforcement), } \\
\text { risk of opportun- } \\
\text { ism, uncertainty, } \\
\text { frequency }\end{array}$ \\
\hline
\end{tabular}

*Institutional theory is very pluralistic and includes branches in economics, sociology, and political science. Information in this table extracts generally from the set of

Table one: Comparing theoretical Perspectives

Source: Malatesta \& Smith, 2014, p.17

3. The Actions And Strategies Football Teams Use/Implement To Reduce Resource Dependency.

Under this heading we will be looking at four major actions and strategies (Mergers, Hiring, Executive Succession and Training) that football teams use in order to reduce their resource dependency on other teams. These are explained in a more detailed and comprehensive manner with self-explanatory examples in the following pages.

\subsection{Mergers}

Merger as a term is often used interchangeably by many to mean amalgamations, take-over and acquisitions to refer to a situation where two or more firms come together and combine into one to avail the benefits of such combinations and re-structuring in the form of merger. This is done in order to face the challenge of increasing competition and to achieve collaboration in business operations. In the literature there are basically four types of mergers and these are; Horizontal Merger, Vertical Merger, Co generic Merger, and Conglomerate Merger (Arora et al., 2012). 
In simple term, mergers happen when two or more different organizations come together to form a single organization. Organizations usually do mergers due to a lack of resources to stand as an independent body and so they decide to merge with a similar organization they have trust in order to become one bigger, stronger, influential and better organization. Mostly, they believe that after doing this merger they will stand a better chance of getting stronger and being able to compete other organizations in the same market since they will be able to have the critical resources they need without depending on other organization in the same environment. Mergers do not always work especially when it is done with an organization that is not trustworthy hence, the reason why trust is an integral pillar in making mergers. When it comes to mergers in football there are so many examples in existence and one among them is the merger between Newcastle West End and Newcastle East End in 1892 to form Newcastle United (Brown, 2014; NUFC, 2018).

Both Newcastle East End and West End had some problems when it comes to the resources they needed to run as a good football team that is powerful enough to compete in the top level of the English league at that time. For that being the case they thought that the best was to solve their problems was to have a merger of the two teams and call it Newcastle United, which will get the team more resources and power to compete against other bigger English teams. Newcastle West End was into a financial problem caused by low attendance and decided to approach East End for a take over. Newcastle East was performing well in the football league and had the financial capabilities to run their team effectively but they lack a good football field, which Newcastle West was fortunate enough to have. So there was a situation where one team needs a particular resource and don't have but the other team has and vise versa, so there was a need for a better solution. Instead of a take over by Newcastle West there was a proposal for a Merger of the two teams and this was realized in May 1892 with the formation of Newcastle United from the merger of Newcastle East End and Newcastle West End. This merger has resulted to the strong nature of present date Newcastle United and the team can now be seen as one of the biggest clubs in the English Premier League. They now have most of the resources they need in order to run the team in a more effective and efficient way and this was as a result of the merger hence, the importance of sometimes making a merger (Brown, 2014; NUFC, 2018).

\subsection{Hiring}

Hiring the right person for a position is one of the most important issues for organizations. However, it has also become a big issue when it comes to the problems some institutions face in making best use of their hired employees. There are cases when a person does well in an interview but when it comes to the implementation of their daily duties the opposite prevails. In other to avoid these problems organizations likewise football teams go under a very rigorous process in selecting or hiring the right person for a particular position. These rigorous processes lead to positive outcomes like, "Giving the job to its friend and not to your friend" or "Not putting square peeks in round holes". Hiring the right person goes a long way in bringing high productivity within an organization, which is the ultimate objective of all institutions (Mamoon, 2013).

"The increased wealth of football clubs has helped to fuel the acquisition (and movement) of talented players, a process known as football labor migration" (Littlewood, 2005, p.1). Taking an example of the English Premier league, which has teams that travel, all the length and breath of the world in order to find the best footballing talent for their teams. Many of these teams see their footballers as the best resource they can have hence comes the importance of hiring them. Teams hiring these footballers by using attractive packages in order not to depend on other football teams for help like loaning them a footballer for a season or two. Hiring your own footballers makes you have full control of the person and this will give you the chance of helping them develop to their fullest potential which will in essence help the club in winning the trophies they desire. Some clubs now in their hiring processes go to African countries in search for talented footballers that usually have a very small price tag. After buying these footballers they train them to the best of their ability and give them the change to play for maybe three or more years after which they sell them to the other teams for a very high price. The good thing is that these teams use the footballers they bought for cheap to play for them and help them achieve their goals, which is a resource they need. After which they also sell those same players for a higher price to other teams, which also helps them in acquiring some money, which they may need. For example a teams objective maybe to get into the premier league top ten and due to this they buy some players which they need at that time and after getting to the top ten they sell some of their players in order to get some cash. This is because the face of football has now changed, from just being a source of entertainment to a very good and reliable source of money for many football team owners. However there are still some football teams specifically the rich ones that buy big and very expensive players in order to win more trophies since it could be an easy way of staying on top (Littlewood, 2005; Jacobs \& Abbot, 2018).

\subsection{Executive Succession}

Executive succession, which is seen as an organization's internally, focused answer to cope with environmental uncertainty and dependencies. It could be seen as a strategic response to environmental contingencies. Executive 
succession can go a long way in reducing environmental dependencies especially if the appointed CEO/Manager is well suited for the existing environmental realities at the time of his tenure (Hillman et al. 2009). Assuming that the problems faced by football teams as organizations are attributed to administrators (e.g. team managers) it is important to consider the caliber of administrators hired by a team. Here we can take for example football team managers as an example for executive succession. The reason why many teams change their football managers are because, they are usually not able to fulfill their promises of bringing the club trophies and signing and scouting for good footballers. In order to solve this problem many football teams now a day try to sign very experienced and influential football managers so that they can attract many players in signing for that club.

Manchester City for example signed Pep Gaurdiola as their manager in 2016 (BBC Sport, 2016) football season this was because they believed that he was the best solution to their problem of not being about to get trophies with all the money they had and so needed a very good tactician to win the trophies. Since Pep was known to be a very good couch who has won a lot of trophies in all the leagues he has gone to the board of Manchester City signed him as their manager. As they expected with his caliber of experience he was able to win them two Premier League trophies (2017-2018, 2018-2019 season) two EFL Cup trophies (2017-2018, 20182019) and one FA Community Shield trophy (2018) with a period of three years (Manchester Evening News, 2019). The good thing about this was that he has a lot of influence when in comes to signing footballers. It is a natural instinct to want to play for a manager that has a winning mentality and can win as will. This helps the team in getting one of the best footballers in the premier league due to the influence of the new manager.

Sometimes footballers sign for a team because of the money and sometimes they do because they think they can get on well with the manager. Football teams after knowing this secret are now trying to sign very influential managers who can lieu other good footballers to play for them. Due to this reason many teams now hire former professional players who were part of the best during their footballing time. An example is Zinedine Zidane who was hired by Real Madrid as head coach in 2016 and was able to win three consecutive champion league trophies in 2016, 2017 and 2018. He was also able to win two Club World Cups, two UEFA Super Cups, one La Liga title and Spanish Super Cup all accomplished in two years five months (Real Madrid, 2018). Many who didn't have the chance to play with him in the same football field would love to be under him as a Coach (manager). Another influence he has will be on the performance of his players since everyone will want to impress him because he was one of the best in his time and this desire to impress him will help in the high performance level of the team. The footballers will also listen to his advice and try to practice to the best of their ability what he says because they know he was the best in his time and his advice maybe important for their careers. This is why football teams are trying to employ influential managers as a practice to reduce resource dependency.

\subsection{Training}

"Training involves changing or improving skills, knowledge, attitudes, or behavior" (Khan, 2012, p.87). Across the globe institutions have started to concentrate on the improvement of the knowledge, skills and capabilities of their workers so as to create a competitive workforce, which can survive in dynamic environments. In order to develop theses skills, knowledge and capabilities managers are forced to crate competitive training programs, which will help them, obtain their ultimate goal of getting a highly productive and competent workforce. These trainings do not only teach workers their roles and responsibilities in the organization but it also encourages them to be more committed to the organization and its goals (Halawi \& Haydar, 2018).

One of the most important strategies and actions football teams use is training its players to their fullest potential so as to avoid the need to spend more money to buy new talents. This is the reason why most of the big teams in the premier league have their own football academies and this could be seen as their shopping center for new talent. Arsenal football club for instance could be seen as a very important example since it is known to be one of the best team that promotes their best young talents from the academy to the senior team. This helps them a long way in saving some cash which they would have used to go buy other expensive players from other teams. If you are promoting a footballer from the academy to the senior team all you have to do is pay his weekly wages but when you are signing from a different team you will also have to pay for their signing fees which may be expensive and so escaping this process helps the team in serving some cash which is an important resource for them. Another thing that teams also do is buy players who they think have a very bright future and train them well at the club. Sometimes this process may take long but it mostly pays since this young talent grows up to be a good player and they use him at the team for some years and later sell him and end up having money to save in the bank. An example was when Arsenal signed Cesc Fabregas from the academy of Barcelona Football Club for 3 million euros (Transfer Market, 2003) and decided to train him for sometime and started playing him at the first team level. After some seasons they sold him back to Barcelona earning the team 35 million pounds (BBC Sports, 2011; The Telegraph, 2011). With the development of football and its high profit levels teams now a day hire professional trainers in order to help in the process of making their footballers play to the best of their ability and in essence win trophies and also help them in not needing to buy or depend on other teams for players. This 
gives them more independence and a competitive advantage in the footballing business.

\section{Discussion And Conclusion}

The major and most important thing one needs to understand when is comes to the resource dependence theory is that of organizations trying to minimize their dependence on other organizations for the supply of scarce resources (Hillman et al., 2009). When an organization supplies you with very sensitive and valuable resources they may have more power over you since they have something that you need from them and this gives them a bargaining power and a competitive advantage. Interdependence lead to uncertainties, which is not a good thing for organizations trying to make, ends meet. Having your own resources as an organization is an integral part of having a longer and productive life. It is the responsibility of organizations (football teams) and their management to work on possible solutions to their resource needs and trying to avoid total dependence on resources from other organization which could be seen as a good way to start. Like mentioned in this article some of the important actions and practices football teams can use are; hiring good footballers, training them professionally, getting good, experienced and influential managers and also making mergers when it is necessary like in the case of Newcastle United. The implication of this paper is that it will go a long way in guiding future researchers on football team strategies in reducing their resource dependency.

\section{Limitations}

The limitations of our study includes the lack of materials when it comes to football and most especially the strategies that football teams use in reducing their resource dependency on other teams. Furthermore, our research examples when it comes to the strategies football teams use in reducing their resource dependency are only limited to England and Spain which is not a total representation of all football teams hence the reason why we can not be able to generalized the findings.

\section{Suggestion For Future Research}

In our research we were only able to find examples and data regarding four strategies that football teams use in reducing their resource dependency and these were mergers, hiring, executive succession and training. However future research can look at other possible strategies like mentioned in the literature such as, political action (influencing political decisions), Contracting, inter teams cooperation and the appointment of influential board members for resource acquiring and dependency reduction. Future research can also try to use the resource based view theory as a theoretical framework in understanding the organizational capabilities and competitive advantages of famous football teams.

\section{References}

Arora, M. \& Kumar, A. (2012) A Study on Mergers and Acquisitions - Its impact on Management and Employees, The International Journal's Research Journal of Economics and Business Studies, Vol. 1(5) 3034

BBC Sport (2011) Cesc Fabregas completes move from Arsenal to Barcelona, Retrieved 14/05/2019 from: https://www.bbc.com/sport/football/14482418

BBC Sport (2016) Guardiola to succeed Manuel Pellegrini as Manchester City boss, Retrieved 14/05/2019 from: https://www.bbc.com/sport/football/35461090

Brown, P. (2014) 1881 And All That: The Lost History of NUFC, Retrieved 10/05/2019 from: https://www.stuffbypaulbrown.com/1881-and-all-that/

Halawi, A \& Haydar, N. (2018) Effects of Training on Employee Performance: A Case Study of Bonjus and Khatib \& Alami Companies, International Humanities Studies Vol. 5(2) 24-45

Hillman, A. J. \& Dalziel, T. (2003) Boards Of Directors And Firm Performance: Integrating Agency And Resource Dependence Perspectives, Academy Of Management Review, Vol. 28, No- 3, 383-396.

Hillman, A.J., Withers, M.C. \& Collins, B.J. (2009) Resource Dependence Theory: A Review, Journal of Management. 35(6) 1404-1427

Jocobs, S. \& Abbot, S. (2018) The Search for Football Talent in Africa-Africa is a Country, Retrieved 14/05/2019 from:https://africasacountry.com/2018/07/the-largest-talent-search-in-football-history

Khan, M. I (2012) The Impact of Training and Motivation on Performance of Employees, Business Review Vol 7(2) 84-95

Littlewood, M. (2005) The Impact of Foreign Player Acquisition on the Development and Progression of Young Players in Elite Level English Professional Football, Liverpool John Moores University

Malatesta, D. \& Smith, C.R. (2014) Lessons from Resource Dependence Theory for Contemporary Public and Nonprofit Management, Public Administration Review, Vol. 74, Iss. 1, pp. 14-25.

Mamoon, Z. (2013) Hiring the Right People for your Organization, Global Journal of Management and Business Research, Vol. 13(8) 67-77 
Manchester Evening News (2019) Pep Guardiola Adds Another Trophy to His Cabinet - This is How Many He Has Won to Date, Retrieved 14/05/2019 from: https:/www.manchestereveningnews.co.uk/sport/football/football news/pep-guardiola-adds-another-trophy-16264746

NUFC (2018) History of our home: The Story of St. James' Park, Retrieved 10/05/2019 from: https://www.nufc.co.uk/club/history/history-of-our-home

Pfeffer, J. \& Salancik, G.R. (1978) The External Control of Organizations: A Resource Dependence Perspective, New York: Harper \& Row.

Real, Madrid. (2018) The French coach won 3 Champions Leagues, 2 Club World Cups, 2 UEFA Super Cups, 1 LaLiga title and 1 Spanish Super Cup, Retrieved 14/05/2019 from https://www.realmadrid.com/en/news/2018/05/zidane-9-titles-in-in-two-years-and-five-months

Rollin J., Alegi, P. C., Giulianotti, R. C., Joy, B. \& Weil, E. (2019) Football, Encyclopedia Britannica. Retrieved 16/05/2019 from: https:/www.britannica.com/sports/football-soccer

The Telegraph (2011) Cesc Fabregas completes move from Arsenal to Barcelona, Retrieved 14/05/2019 from: https://www.telegraph.co.uk/sport/football/teams/arsenal/8702013/Cesc-Fabregas completes-move-fromArsenal-to-Barcelona.html

Transfer Market (2003) Transfer History, Retrieved 14/05/2019 from: https://www.transfermarkt.com/cescfabregas/transfers/spieler/8806/transfer id/12757

Ulrich, D. \& Barney, J.B. (1984) Perspectives in Organizations: Resource Dependence, Efficiency, and Population, Academy of Management Review. Vol. 9, No. 3, 471-481

\section{DECLARATION}

I, Samba Sowe declare to the best of my knowledge, the submission is original, the submission is not being considered elsewhere, there is no conflict of interests and, the authors agree to grant the first editing / publishing rights to the journal upon acceptance. 